\title{
Report on the Present State of Knowledge with regard to the Habits and Migrations of the Mackerel (Scomber scomber).
}

\author{
By \\ E. J. Allen, B.Sc., \\ Director of the Plymouth Laboratory. \\ Prepared by order of the Council of the Marine Biological Association for the use of \\ H.M. Inspectors of Irish Fisheries.
}

THE mackerel (Scomber scomber) is a pelagic* and migratory fish, which during the warmer months of the year frequents the coastal waters in the northern temperate region of the Atlantic. The whole form of the fish is evidently well fitted for swift motion and the freeswimming mode of life. The spindle-shaped outline of the body, its perfect curves and rounded surfaces, the absence of all irregular projections which would tend to retard forward movement, the great muscular development of the tail, and the deep forking of the caudal fin, combine to produce an almost ideal adaptation for propulsion at high speed through the water. $\dagger$

The mackerel may be called also a pelagic-feeding fish, in contradistinction to fishes such as many of the family of the Gadidx, which are "ground " feeders; that is to say, the mackerel feeds entirely upon free-swimming organisms, whilst the ground-feeders hunt at the bottom and amongst rocks, capturing prey which is not pelagic. The difference is an important one in considering the habits of the fish.

During, at any rate, a great portion of the year mackerel swim in shoals or schools. These shoals often contain an immense number of fish, and the fish belonging to any particular shoal are usually of about the same size. Schools of small fish and schools of large may be found in the same neighbourhood at the same time, but they appear to remain separate. Little is known as to the manner in which fish keep together in shoals. From observations made in the Aquarium at the Plymouth Laboratory, Bateson $\ddagger$ concludes that grey mullet keep together by sight. In this case also the shoals appear to arrange them-

* The term pelagic is used in the sense in which it was originally employed by Johannes Müller, and subsequently by Haeckel. The mackerel is not a pelagic fish in the restricted sense adopted by Günther, who employs this term to include only such free-swimming fishes as inhabit the open ocean at a great distance from land.

$+C f$. Bashrord Dean, Fishes, Living and Fossil, pp. 2-6.

‡ Journ. Mar. Biol. Assoc., N.S., vol. i. pp. 249-250.

NEW SERIES, - VOL. V. NO, 1 , 
selves according to the sizes of the fish. The shoal does not seem to have any definite leader, the fish following any individual which makes a dart in a particular direction. Bateson found that at night the fish lay on the surface of the water, with their heads pointing in different directions, and that they did not move about in shoals. Similar observations on the mackerel have never been made. Fulton suggests that the iridescent colouring on the sides of many fishes may assist them in keeping together in shoals.*

Distribution.- - The mackerel (Scomber scomber) occurs on the Atlantic coast of Europe, from Bergen in Norway, southward to the Straits of Gibraltar. $\dagger$ It is found also in the Mediterranean, being taken in large numbers along the Spanish coast, the south coast of France, the coasts of Corsica, and in the Adriatic. Mackerel are also mentioned as being captured on the coasts of Tunis and of Morocco, but no definite statement has been found as to whether the species is Scomber scomber or Scomber colias.

In America Scomber scomber is found off the Atlantic coast, from Cape Hatteras in the south, as far north as the coast of Labrador. From Cape Hatteras northwards to the shores of Long Island it is, however, only met with at some distance from land; hence in America it actually approaches the coast from Long Island to the coast of Labrador. In many seasons mackerel are only found as far north as Newfoundland, and there is little fishing of importance even so far north as this.

An allied species, Scomber colias, the Coly or Spanish mackerel of Europe, chub or thimble-eyed mackerel of America, has a more southern distribution, extending on the European coasts as far north as the south coast of Ireland, where, however, it is not taken in numbers, and southwards to Madeira. It is also plentiful at the Cape of Good Hope, where numbers were captured in 1889 and 1890 by American mackerel vessels, which had proceeded there for the purpose. $\ddagger$ In American waters the species is found from the Gulf of Mexico to the coast of Maine, and also on the Pacific coast of the United States.

There is also a fish known in America as the "Spanish Mackerel" (Scomberomorus maculatus), which extends on the east coast from Cape Ann to Brazil. It is common in the Gulf of Mexico, but rare or unknown about Cuba.

* Fishery Board for Scotland. 10th Report, 1891, p. 342.

+ Occasional specimens may be taken further north and south than the limits here indicated, but they are not present in sufficient numbers to give rise to a fishery.

‡ Report U.S. Fish. Com., 1889-91, p. 203.

$\S$ Jordan and Everman, "Cheek-list of Fishes." Report U.S. Fish. Com., 1895. 
Breeding.-The spawning of the mackerel was first investigated by Sars, * in 1865, on the coast of Norway. This naturalist found that the fish spawned near the coast, sometimes nearer than at others, and that the eggs floated at the surface of the sea like those of the cod, from which they could be distinguished by the presence of an oil globule. The same facts were ascertained in 1871 by $\mathrm{Mr}$. Matthias Dunn, who obtained the spawning fish on the south coast of Cornwall, about six miles from land, on the night of May 10th. $\dagger$

The subject has since been investigated by other naturalists, more especially by Cunningham, $\ddagger$ at Plymouth, who has figured and described the eggs and various stages of the larval fish.

The breeding season varies in different localities, occurring considerably later in the year in the north than in the south.

In the Mediterranean (Gulf of Marseilles) Marion $\S$ found mackerel with ripe reproductive organs chiefly in March and April, and considers these two months to be the principal spawning period. No ripe fish were ever found after May 19th. From the size of larvæ taken in May, the same author comes to the conclusion that some fish must spawn as early as January.

At Plymouth the spawning fish are found from 14 to 50 miles from the coast. Spawning takes place from the end of May to the latter part of July, and, according to Cunningham, appears to be distinctly limited within those times. \|

On the south-west coast of Ireland, Green I states that spawning takes place in May and June. Holt** obtained ripe eggs off this coast in the tow-net on April 30th and May 4th. Mackerel examined on April 1st were half and three-parts ripe. On May 12th, out of 50 fish all the males were ripe. The females were mostly half and three-quarters ripe, but a few were ripe. Ripe fish were also seen as late as June 20th, the specimen examined at the latter date being called by Holt "a small autumn mackerel." The same author states that it appears that successive shoals approach the coast at different points and spawn in the neighbourhood, the larger fish being the first to arrive.

* Report for 1875. English translation. Report of U.S. Fish. Com., 1877.

† Land and Water, May 20, 1871, p. 353.

¥ Journ. Mar. Biol. Assoc., N.S., vol. i. p. 25.

$\S$ Ann. Mus. Nat. Hist. Marseille Zool. Appliquée, i., 1889.

|| Natural History of Marketable Marine Fishes. London: Macmillan \& Co., Ltd., 1896.

ศा "Notes on the Irish Mackerel Fisheries." Bull. U.S. Fish. Com., 1893.

** (1) "Survey of Fishing Grounds on the West Coast." Royal Dublin Society. Report of Council for 1891.

(2) Scientific Transactions Roy. Dublin Soc., 1893. Fishes. 
Sars concludes that on the coast of Norway the spawning is confined to the first fortnight in July.

From the information derived from mackerel fishermen in America, and published in the Reports of the United States Fish Commission,** it is evident that the breeding season of the fish there also varies on different parts of the coast, becoming later the further north one gets. Although no definite statement by the naturalists of the Commission as to the exact limits of the spawning period in different localities has been published, it would appear that on the New England coast spawning takes place principally in May and June, whilst in the Gulf of St. Lawrence it is later, occurring during the latter half of June and in July. On the other hand, in the south (south-east of Cape Henry, and off the Virginia coast) spent fish were taken in April. $\dagger$

The following table shows the chief spawning period of the mackerel in different localities, according to the information at present available:-

\section{Locality. Spawning Period,}

Mediterranean (Gulf of Marseilles) . March and April. (Possibly also

South-west of Ireland. January and February.)

South-west of England (off Plymouth) May and June.

Norway. End of May to end of July. First half of July.

America.

Virginia Coast
New England Coast

LOCALITY

(Massachusetts Bay)

Gulf of St. Lawrence.
Spawning Period. April.

May and June.

. End of June and in July.

Rate of Growth.-Considerable uncertainty exists as to the rate of growth of the mackerel, and the views of the authors who have paid attention to the subject differ widely. The largest amount of information bearing on the question has been collected by Marion and Gourret on the Mediterranean coast of France. $\neq$ Young mackerel, from 2 to $10 \mathrm{~cm}$. ( $\frac{3}{4}$ to 4 inches), are caught in numbers at Marseilles and Nice, more especially at the latter place, in April and May, and Marion and Gourret both regard these fish as the young of the year. This, however, compels them to assume that the spawning season begins

\footnotetext{
* See especially Report U.S. Fish. Com., 1881.

+ Report U.S. Fish. Com., 1895.

¥ Ann. Mus. Nat. Hist. Marseille Zool. Appliquée, 1889-91.
} 
as early as January. As already stated, however, spawning fish were never obtained by them until March and April. The small fish, $2-10 \mathrm{~cm}$. ( $\frac{3}{4}$ to 4 inches) long in April and May, are considered to have reached $10-13 \mathrm{~cm}$. (4 to 5 inches) by August, and 15 to $18 \mathrm{~cm}$. (6 to 7 inches) by the end of the year. In the following February fish from 20 to $24 \mathrm{~cm}$. ( 8 to $9 \frac{1}{2}$ inches) are taken, the age of which Marion considers to be twelve months; and since these fish have their reproductive organs well developed, he is compelled to ask, not without some hesitation, Does the mackerel spawn when only one year old?

The question of the rate of growth of mackerel in the English Channel is discussed by Cunningham,* and he also gives detailed measurements of a large number of these fish caught in fine-meshed nets in November, which varied in length from 15 to $20 \mathrm{~cm}$. (6 to 8 inches). The length of the larva at the time of hatching he states to be $4.23 \mathrm{~mm}$ † $\mathrm{He}$ also describes some young mackerel obtained by Holt + in the North Sea. Twelve specimens taken on July 9 th measured from 6 to $9 \mathrm{~mm}$. ( 24 to $\cdot 36 \mathrm{inch})$; three taken on the 27 th and 28 th July were from 13.5 to $19 \cdot 25 \mathrm{~mm}$. ( 54 to $\cdot 77$ inch). The largest of the specimens already showed the adult characters, and Cunningham regards them as being from one to two months old.

Day§ states, on the authority of Matthias Dunn, that at Mevagissey young mackerel are plentiful in the bays in August and September, when they are about 3 inches ( 7 to $8 \mathrm{~cm}$.) long, reaching 6-7 inches (16 to $18 \mathrm{~cm}$.) in November. They then leave for the deep sea, and return again in the following June, when they are 8 or 9 inches (21 to $23 \mathrm{~cm}$.) long.

The best account of the growth of the mackerel in America is given on the authority of Capt. Atwood, $\|$ it being stated that the specimens were seen by Prof. Agassiz. According to this account the mackerel spawn in Massachusetts Bay in May and the first half of June. On July 10 th schools of mackerel 2 inches $(5 \mathrm{~cm}$.) long were present in the bay, which had grown to about twice the weight (say 7-8 $\mathrm{cm}$. long) on August 4th. During the latter part of October young fish from $6 \frac{1}{2}$ to 7 inches (say 16 to $18 \mathrm{~cm}$.) were taken.

In the following table these various statements are placed side by side, all the evidence at present available being included :-

\footnotetext{
* Journ. Mar. Biol. Assoc., N.S., vol. ii. pp. 230 to 233.

† Journ. Mar. Biol. Assoc., N.S., vol. ii. p. 71.

¥ Holt himself also mentions these fish. Journ. Mar. Biol. Assoc., vol. ii. p. 396.

$\S$ British Fishes, vol. i. p. 89.

\| Report U.S. Fish. Com., 1881, p. 114.
} 
Table showing the published evidence available for determining the rate of growth of the Mackerel.

\begin{tabular}{|c|c|c|c|c|c|c|c|c|}
\hline & \multicolumn{2}{|l|}{ Marseille and Nice. } & \multicolumn{2}{|c|}{$\begin{array}{l}\text { MEvagissey } \\
\text { (CoRnWaLL). }\end{array}$} & \multicolumn{2}{|c|}{ Plymouth (Devon). } & \multicolumn{2}{|c|}{ Massachusettr. } \\
\hline & Length of fish captured. & 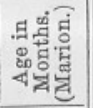 & Length of fish. & 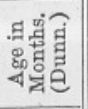 & Length of fish. & 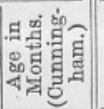 & Length of fish. & 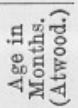 \\
\hline January & Spawning (?) & - & - & - & - & - & - & - \\
\hline February .................... & $\begin{array}{l}\text { Spawning (?) } \\
20-24 \mathrm{~cm} .\end{array}$ & 12 & - & - & - & - & - & - \\
\hline March .................. & $\begin{array}{l}\text { Spawning. } \\
\text { End of Month: } \\
5-5 \cdot 8 \mathrm{~cm} \text {, in quantity } \\
\text { at Nice; } 15 \mathrm{~cm} ., \text { Mar- } \\
\text { seille. }\end{array}$ & 2 & - & - & - & - & - & - \\
\hline April $\quad . . . . . . . . . . . . . . . .$. & $\begin{array}{l}\text { Spawning. } \\
\text { End of Month : } \\
4.5-12 \mathrm{~cm} \text {. (Nice); } \\
4-6 \mathrm{~cm} \text {. (Marseille). } \\
4-8.5 \mathrm{~cm} .\end{array}$ & 3 & - & - & - & - & - & - \\
\hline May ....................... & $\begin{array}{l}\text { *2-6 cm. (quantity), Mars. } \\
10-20 \mathrm{~cm} \text {. " " " } \\
10-15 \mathrm{~cm} . \\
11 \mathrm{~cm} ., \text { plentiful. } \\
6-11 \mathrm{~cm} ., \text { Nice. }\end{array}$ & $2-4$ & Spawning. & - & $31-33 \mathrm{~cm}$ & 24 & Spawning. & - \\
\hline
\end{tabular}




\begin{tabular}{|c|c|c|c|c|c|c|c|c|}
\hline June....................... & $\begin{array}{c}12-15 \mathrm{~cm} \\
10 \mathrm{~cm}\end{array}$ & $\begin{array}{l}6 \\
4\end{array}$ & $\begin{array}{l}\text { Spawning. } \\
21-23 \mathrm{~cm} .\end{array}$ & 12 & $\begin{array}{l}\text { Spawning. } \\
22-23 \mathrm{~cm} .\end{array}$ & 12 & Spawning till 10th. & - \\
\hline July ............... & $\begin{array}{l}15-20 \mathrm{~cm} \\
10-13 \mathrm{~cm}\end{array}$ & - & Spawning. & - & $\begin{array}{l}\text { Spanoning. } \\
\text { 9th. 6-9 mm. (North Sea). } \\
\text { 27th. } 1 \cdot 35-1 \cdot 925 \mathrm{~cm} \text {. (N.S.) }\end{array}$ & $1-2$ & $5 \mathrm{~cm}$. & 2 \\
\hline August.................. & $10-13 \mathrm{~cm}$. & $4-5$ & $7-8 \mathrm{~cm}$ & 3 & - & - & $7-8 \mathrm{~cm}$ & 3 \\
\hline September ............ & - & - & - & - & $\begin{array}{l}\text { 30th. } 13.8 \mathrm{~cm} . \quad \text { (1 speci- } \\
\text { men.) }\end{array}$ & 14 & - & - \\
\hline October $\ldots$ & - & - & - & - & $18-25 \mathrm{~cm}$ & $\begin{array}{c}15 \text { to } \\
16\end{array}$ & $\begin{array}{l}\text { End of Month : } \\
16-18 \mathrm{~cm} .\end{array}$ & $5-6$ \\
\hline November ............. & 15-18 cm. (Marseille). & 9 ? & $16-18 \mathrm{~cm}$. & 6 & $15-20 \mathrm{~cm}$. & 16 & - & - \\
\hline December ............. & - - & - & - & - & - & - & - & - \\
\hline
\end{tabular}

At Marseille were taken :1891. May 10th.

30 kilos, $2-3 \mathrm{~cm}$. long.

11 th to 17 th. $31,3-4 \mathrm{~cm}$. ,

, 23rd to 26 th. 6 ", $3-5 \mathrm{~cm}$. ,

, 29th to 31 st. $25,3-6 \mathrm{~cm}$. ,

Mixed with these :-

415 kilos, $10-15 \mathrm{~cm}$.

$298,10-20 \mathrm{~cm}$.

20 ," $15-25 \mathrm{~cm}$.

$120,, \quad 20-25 \mathrm{~cm}$.

$25, \quad 20-30 \mathrm{~cm}$. 
The rate of growth required to meet the views of the different observers is approximately represented in the following table:-

\begin{tabular}{|c|c|c|c|c|c|c|c|c|}
\hline \multirow{2}{*}{\multicolumn{3}{|c|}{ AGE. }} & $\begin{array}{l}\text { MEDITER- } \\
\text { RANEAN. }\end{array}$ & Cornwall. & $\begin{array}{l}\text { BRITISH } \\
\text { CoAsts. }\end{array}$ & AMERICA. & Cop. & HERRING. \\
\hline & & & $\begin{array}{l}\text { Marion and } \\
\text { Gourret. }\end{array}$ & Dunn. & Cunningham. & Atwood. & Dannevig. & Meyer. \\
\hline \multicolumn{3}{|c|}{$\begin{array}{l}1 \text { month } \ldots \\
2 \text { months ... }\end{array}$} & $4-\overline{\mathrm{cm}}$. & 二 & $\begin{array}{r}1.35 \text { to } \\
1.925 \mathrm{~cm}\end{array}$ & - & $\begin{array}{l}1.5 \mathrm{~cm} . \\
5.5 \mathrm{~cm}\end{array}$ & $1.7 \mathrm{~cm}$ \\
\hline 3 & ", & $\ldots$ & $6 \mathrm{~cm}$ & $7-8 \mathrm{~cm}$. & - & $7-8 \mathrm{~cm}$ & $7.0 \mathrm{~cm}$. & $4 \cdot 5-5 \mathrm{~cm}$ \\
\hline $\begin{array}{l}4 \\
5\end{array}$ & " & $\cdots$ & $10-11 \mathrm{~cm}$. & - & 一 & - & $8.5 \mathrm{~cm}$. & $5 \cdot 5-6 \mathrm{~cm}$. \\
\hline 6 & ", & $\ldots$ & $14-15 \mathrm{~cm}$. & $16-\overline{18} \mathrm{~cm}$ & 二 & $16-\overline{18} \mathrm{~cm}$ & & $00-12 \mathrm{~cm}$. \\
\hline 7 & $"$ & $\ldots$ & - & - & - & - & - & - \\
\hline $\begin{array}{l}8 \\
9\end{array}$ & ", & $\cdots$ & $17-18 \mathrm{~cm}$. & - & - & 一 & - & - \\
\hline 10 & $"$ & $\ldots$ & $\overline{-}$ & $\bar{z}$ & 二 & - & $\overline{-}$ & 二 \\
\hline 11 & ", & $\ldots$ & - & - & - & - & - & 二 \\
\hline $\begin{array}{l}12 \\
13\end{array}$ & ", & $\cdots$ & $23-24 \mathrm{~cm}$ & $21-23 \mathrm{~cm}$ & $22-23 \mathrm{~cm}$ & - & - & - \\
\hline 14 & $"$ & $\cdots$ & E & 二 & - & 二 & 二 & 二 \\
\hline 15 & ," & $\ldots$ & - & - & - & - & - & - \\
\hline $\begin{array}{l}16 \\
22\end{array}$ & $"$ & $\cdots$ & - & - & $14-20 \mathrm{~cm}$ & - & $\overline{-}$ & - \\
\hline & & & & & & & $35-40 \mathrm{~cm}$. & \\
\hline
\end{tabular}

Two columns are added showing the rate of growth of the cod, as determined by Dannevig from specimens reared in a large pond, and of the herring, as determined by Meyer for the river Schlei, the observations in the latter case being confirmed by the rate of growth of larvæ, which Meyer succeeded in rearing in confinement.*

It will be seen that the rate of growth suggested by Cunningham is much slower than that regarded as probable by the other observers. $\mathrm{He}$ considers the fish from 16 to $21 \mathrm{~cm}$., which are taken in November, as being derived from the spawning of the previous year, being therefore 16 months old. At the same time he regards the mackerel, 22 to $23 \mathrm{~cm}$. long in June, as only one year old, and explains the difference as due to the great individual variation in growth rate.

There are no doubt great difficulties in the way of accepting the very rapid growth suggested by the French and American observers, and by Mr. Dunn. If their view is correct, the rate of growth of the mackerel will be much more rapid than that of the herring, approaching more nearly that of the cod reared by Dannevig. The question is, however, one which can only be settled by further research.

Size And Maturity.-With regard to the size at which the mackerel begins to breed, practically nothing is known. Marion states $\dagger$ that the fish which are 20-24 cm. (9 inches) long in February, and : :hich he regards as one year old, have the reproductive organs well advanced.

* See Cunningham. Journ. Mar. Biol. Assoc., N.S., vol. ii. pp. 223 and 236.

† Ann. Mus. Nat. Hist. Marseille Zool. Appliquée, i., 1889, p. 87. 
At Plymouth in June Cunningham* found no signs of maturity in fish $22 \cdot 2$ to $23 \cdot 5 \mathrm{~cm}$. (8.7-9.2 inches) long, nor in one female of $27 \cdot 4 \mathrm{~cm}$. (10.7 inches). The smallest ripe female, which he records, is $29.5 \mathrm{~cm}$. (11.5 inches), and the smallest ripe male $30.3 \mathrm{~cm}$. (11.8 inches). His observations are, however, far too few in number to enable any general conclusions to be drawn.

FooD.-It has already been stated that the mackerel is a pelagicfeeding fish; that is to say, it feeds upon free-swimming organisms, and not upon those which live on the bottom of the sea. The food of this fish may be regarded as of two different kinds, and it adopts two different methods for procuring it. In the first place it feeds upon the smaller forms of the plankton, copepods and other crustaceans, larvæ of crustaceans, molluscs, echinoderms and worms, diatoms, and even siphonophores and medusæ, obtaining its food like the herring, by straining the sea-water through its gill-rakers, as it swims open-mouthed through the sea. This method of feeding would appear to furnish the fish with its principal food supply during the spring and early summer, when it first approaches the coast. During the latter part of summer, however, and in the autumn, small fish of other species become abundant, and the mackerel then makes these its chief article of diet. Young herring, sprats, pilchards, and rockling are all devoured. These young fish are hunted by sight, the mackerel darting at them and capturing them individually. The fine condition of the autumn fish is due to the abundance of food which they obtain in this way.

In its early stages the mackerel lives upon the small organisms of the plankton, including larval fish. Marion found in the stomachs of small mackerel at Nice, taken in May, copepods, zoeas of brachyura, and sardine larvæ.

Migrations.-The migrations of the mackerel have long been a subject of speculation, but it cannot yet be said that much definite knowledge, either as to their extent, or the causes which bring them about, has been acquired. The recorded facts, sufficiently trustworthy and precise to be of practical use in the consideration of the subject, are not numerous. The importance of the collection of statistics showing the quantities of fish landed at various ports during the different months of the year has not long been recognised, and without independent knowledge as to the localities where the fish have been caught those statistics which are published are very liable to lead to false conclusions. 
A comparative study of the Board of Trade statistics for England and Wales has, however, proved of service, whilst the tables compiled by the Irish Inspectors are of value, principally in showing the fluctuations of the fishery in that country from year to year. By far the most satisfactory statistics are those which are now being published by the French authorities, but in their present complete form these only date from the end of the year 1895. For the two years previous to this valuable notes, giving statistics for some of the more important ports, appeared from month to month in the Bulletin des Péches Maritimes, and these have been of considerable use. Sars * gives much reliable information about the Norwegian mackerel fisheries, and Marion and Gourret $\uparrow$ about those of the Mediterranean coast of France. A considerable amount of information as to the mackerel fishery on the American coast is contained in the Reports and Bulletins of the United States Fish Commission, and these have here been freely made use of.

From the above sources a number of tables have been constructed, which give an insight into the distribution of the mackerel fisheries at different times of the year. In considering the information in these tables it must be constantly borne in mind that the figures represent the quantities of fish landed in particular districts or at particular ports. In the absence of definite information as to where the fish were caught, and also of the number and fishing power of the boats employed in the fishery, great care must be exercised in drawing conclusions from them as to the relative abundance of fish in different localities. They are of more use in giving an idea of the abundance of fish in the same locality at different times of the year.

Table I., which is to a large extent an arbitrary compilation, based, however, where possible on the statistical tables which follow, shows at what times of the year mackerel are present at the places mentioned, and during which months they are taken in the largest quantities at each place. Numbers from 0 to 5 are used to indicate the relative abundance; but the series is independent for each place, the figure 5 representing the maximum for the year at the place referred to. Thus the figure 5 stands opposite the month of May for both the south-west of Ireland and the south of England. This means that in both these districts mackerel fishing is most productive during that month. It does not imply that the fish are as abundant in the one district as in the other.

Where possible Table I, is constructed from the actual figures for three years. Where this cannot be done the results are derived

* Report for 1875. English Translation in Report U.S. Fish. Com., 1877, pp. 667-680.

† Ann. Mus. Nat. Hist. Marseille Zool. Appliquée. 
TABLE I., showing the relative quantity of Mackerel landed at each of the places mentioned at different times of the year. The numbers 1 to 5 are independent for each place, 5 representing the maximum at the place to which it refers.

\begin{tabular}{|c|c|c|c|c|c|c|c|c|c|c|c|c|c|c|}
\hline \multirow[t]{2}{*}{. } & \multicolumn{2}{|c|}{ MEDITERRANEAN. } & \multicolumn{9}{|c|}{ WEST COAST OF EUROPE. } & \multicolumn{3}{|c|}{ EAST COAST OF AMERICA. } \\
\hline & $\begin{array}{l}\text { MAR- } \\
\text { SEILLE. }\end{array}$ & Cette. & Portugal. & $\begin{array}{l}\text { Wrst OF } \\
\text { France. }\end{array}$ & $\begin{array}{c}\text { SoUTH OF } \\
\text { ENGLAND. } \\
\text { Princi- } \\
\text { pally at } \\
\text { Western } \\
\text { Ports. }\end{array}$ & $\begin{array}{r}\text { WEST OF } \\
\text { ENGLAND. }\end{array}$ & $\begin{array}{c}\text { SOUTH- } \\
\text { WEST OF } \\
\text { IRELAND. }\end{array}$ & $\begin{array}{l}\text { WEST OF } \\
\text { SCOTLAND. }\end{array}$ & NorWay. & $\mid \begin{array}{c}\text { Nonth of } \\
\text { FRANCE. } \\
\text { Eastern } \\
\text { portion. } \\
\text { St. Varley- } \\
\text { sur- } \\
\text { Somme \& } \\
\text { Dieppe. }\end{array}$ & $\begin{array}{l}\text { North } \\
\text { SEA. } \\
\text { Southern } \\
\text { part. }\end{array}$ & $\begin{array}{c}\text { CAPE HAT- } \\
\text { TERAS TO } \\
\text { CAPES OF } \\
\text { DELA- } \\
\text { WARE. }\end{array}$ & $\begin{array}{c}\text { NEW } \\
\text { ENGLAND } \\
\text { COAST. }\end{array}$ & $\begin{array}{l}\text { GULF OF } \\
\text { ST. LAW- } \\
\text { RENCE. }\end{array}$ \\
\hline January .... & 1 & 0 & - & 1 & 1 & 0 & 1 & 0 & 0 & 0 & 0 & 0 & 0 & 0 \\
\hline February ......... & 1 & 0 & - & $0-2$ & 1 & 0 & 1 & 0 & 0 & 0 & 0 & 0 & 0 & 0 \\
\hline March ..... & $\mid \begin{array}{c}\text { spawning } \\
1\end{array}$ & 1 & - & 2 & 3 & 2 & 2 & 0 & 0 & 0 & 0 & $0-1$ & 0 & 0 \\
\hline April................ & $\begin{array}{c}\text { spawning } \\
2\end{array}$ & 4 & - & 3 & 4 & 4 & 4 & 0 ? & $\begin{array}{c}0 \\
0\end{array}$ & 2 & 0 & 5 & 0 & 0 \\
\hline May ................ & 3 & 5 & plentiful & 5 & $\begin{array}{c}\text { spawning } \\
5\end{array}$ & 5 & $\begin{array}{c}\text { spawning } \\
5\end{array}$ & present & $\left.\begin{array}{c}\text { about } 20 \text { th } \\
3 ?\end{array}\right\}$ & 2 & 1 & - & $\begin{array}{l}\text { spawning } \\
\text { present }\end{array}$ & 0 \\
\hline June ............... & 4 & 3 & plentiful & 4 & $\left|\begin{array}{c}\text { spawning } \\
4\end{array}\right|$ & 4 & $\begin{array}{c}\text { spawning } \\
4\end{array}$ & ditto & 5 & 3 & 2 & - & $\left|\begin{array}{c}\text { spawning } \\
\text { ditto }\end{array}\right|$ & present \\
\hline July ................ & 5 & 2 & plentiful & 2 & $\left|\begin{array}{c}\text { spawning } \\
3\end{array}\right|$ & 2 & 2 & 一 & $\begin{array}{l}\text { spawning } \\
3 \text { ? }\end{array}$ & 5 & 2 & 一 & present & $\begin{array}{l}\text { spawning } \\
\text { present }\end{array}$ \\
\hline August .... & 4 & 1 & - & 3 & 2 & 2 & $\begin{array}{l}\text { end of } \\
\text { month, or } \\
\text { beginning } \\
\text { of Sept. }\end{array}$ & $\underset{\text { Orkneys }}{\text { At }}$ & $?$ & 4 & 1 & - & ditto & present \\
\hline September ...... & $3-5$ & 1 & - & 4 & 3 & 1 & $5 ?$ & $?$ & Autumn & 5 & 4 & 一 & ditto & ditto \\
\hline October............. & 2 & 1 & - & 3 & 2 & 1 & $3 ?$ & $?$ & fjords & 1 & 5 & - & ditto & ditto \\
\hline November ...... & $0-1$ & 0 & - & 2 & 1 & 1 & 1 & ? & 0 & 0 & 3 & - & ditto & ditto \\
\hline December.......... & $0-1$ & 0 & - & 1 & 2 & 0 & 1 & - & 0 & 0 & 1 & 一 & 0 & 0 \\
\hline
\end{tabular}


from such general information as it has been possible to find, and the table does not pretend to anything more than rough approximation to accuracy.

Table II., compiled from the English and French official statistics, gives the average amount for three years of mackerel landed during each year on the east, south, and west coasts of England and Wales, and at Gravelines and St. Varley-sur-Somme on the north, Douarnenez on the west, and Cette on the south coasts of France. The full statistics for the French coasts are only published for 1896, but the ports selected may be regarded as representative. Cette and Douarnenez have the largest mackerel fisheries on their respective coasts. The fishery at St. Varley-sur-Somme, on the other hand, is less important than that at either Boulogne or Fécamp; but the statistics for this port are selected in preference, because the majority of the mackerel landed at the two other ports in the spring are the products of the fishery carried on off the south-west coast of Ireland. The figures for St. Varley-sur-Somme are therefore "more representative of the fishing on the north coast of France. Gravelines, where mackerel are only landed in quantity during two months of the year, represents the important autumn fishery in the North Sea.

Table III. gives the actual quantities of mackerel landed on the three coasts of England and Wales for the three years 1893, 1894, and 1895, and shows the fluctuations of the fisheries from year to year.

Table IV. contains similar information for some representative French ports for 1894, 1895, and 1896.

Table V. gives the quantities landed at the more important French ports during 1896 .

With the information contained in these tables it is possible to form a fairly correct idea of the distribution of the mackerel on the coasts of both Europe and America during the different months of the year. As the conditions change somewhat slowly, it will be most convenient for our purpose to consider them during periods of two consecutive months.

JanUARY and February : Europe.-Very few mackerel are taken in any locality during these months. Those which are captured are chiefly found in the western part of the English Channel, off the south-west coast of Ireland,* off the west coast of France (Douarnenez), and in small numbers in the Gulf of Marseille. Those caught in the English Channel are found 30 to 40 miles from the coast, some being taken at this distance south of Start Point, others south of Plymouth. ${ }^{+}$There is

* Inspector's Report, 1895. (Table, Spring Mackerel Fishery.)

† Journ. Mar. Biol. Assoc., vol. ii. p. 7. 
TABLE II., showing the average quantity of Mackerel landed during each month on the coasts of England and Wales, and at certain French ports, compiled from the official returns for three years.

\begin{tabular}{|c|c|c|c|c|c|c|c|}
\hline \multicolumn{4}{|c|}{ ENGLAND AND WALES. } & \multicolumn{4}{|c|}{ FRANCE. } \\
\hline & & & & \multicolumn{2}{|c|}{ NoRth. } & West. & SоUтн. \\
\hline & $\begin{array}{c}\text { EAST Coast. } \\
\text { Average, 1893-1895. }\end{array}$ & $\begin{array}{c}\text { Sочтн Сольт. } \\
\text { Average, 1893-1895. }\end{array}$ & $\begin{array}{c}\text { West CoAst. } \\
\text { Average, 1893-1895. }\end{array}$ & Gravelinks. & $\begin{array}{l}\text { ST. VARLEY-SUR- } \\
\text { SoMmE. } \\
\text { Average, 1894-1896. }\end{array}$ & $\begin{array}{c}\text { DouArnienez. } \\
\text { Average, 1894-1896. }\end{array}$ & $\begin{array}{c}\text { Cетте. } \\
\text { Average, 1895-1896. }\end{array}$ \\
\hline January ..................... & $\begin{array}{c}\text { Cwts. } \\
-\end{array}$ & $\begin{array}{l}\text { Cwts. } \\
124\end{array}$ & $\begin{array}{c}\text { Cwts. } \\
-\end{array}$ & Kilos. & $\begin{array}{c}\text { Kilos. } \\
-\end{array}$ & $\begin{array}{l}\text { Kilos. } \\
\quad 908\end{array}$ & $\begin{array}{c}\text { Kilos. } \\
-\end{array}$ \\
\hline February.................... & - & 72 & - & - & - & 49,984 & - \\
\hline March ...................... & - & 10,137 & 1,597 & - & - & 37,689 & 920 \\
\hline April ....................... & - & 31,829 & 44,327 & - & - & 236,960 & 60,377 \\
\hline May ......................... & 68 & 65,781 & 60,011 & - & 1,650 & $1,138,175$ & 76,850 \\
\hline 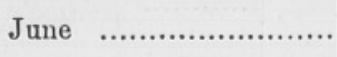 & 2,756 & 30,371 & 31,300 & - & 38,667 & 437,403 & 49,500 \\
\hline 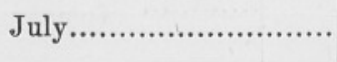 & 5,247 & 10,719 & 3,739 & $\begin{array}{r}945 \\
1896 \text { only. }\end{array}$ & 73,333 & 34,187 & 10,900 \\
\hline 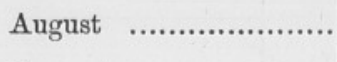 & 124 & 4,880 & 1,397 & $\begin{array}{r}1,275 \\
1896 \text { only. }\end{array}$ & 56,000 & 214,450 & 3,500 \\
\hline September ................... & 15,600 & 9,498 & 637 & 149,140 & 66,207 & 446,138 & 2,640 \\
\hline October $\ldots \ldots \ldots \ldots \ldots \ldots \ldots$ & 32,675 & 3,761 & 136 & $\begin{array}{c}\text { Average, } 1894-95-96 \\
135,265\end{array}$ & 8,167 & 225,672 & 1,350 \\
\hline November .................. & 8,406 & 645 & 95 & - & - & 76,280 & 1,003 \\
\hline December ................. & 72 & 2,277 & 1 & - & - & 27,044 & 1,006 \\
\hline
\end{tabular}


TABLE III., showing the quantity of Mackerel landed during each month of the year on the coasts of England and Wales, for the years 1893, 1894, and 1895, compiled from the official returns.

\begin{tabular}{|c|c|c|c|c|c|c|c|c|c|}
\hline & \multicolumn{3}{|c|}{ ENGLAND.-(EAST COAST). } & \multicolumn{3}{|c|}{ ENGLAND.-(South CoAst). } & \multicolumn{3}{|c|}{ ENGLAND AND WALES.-(WEBT COAST). } \\
\hline & 1893. & 1894. & 1895. & 1893. & 1894. & 1895. & 1893. & 1894. & 1895. \\
\hline 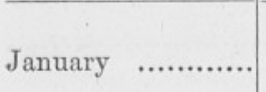 & $\begin{array}{l}\text { Cuts. } \\
-\end{array}$ & $\begin{array}{l}\text { Cuts. } \\
-\end{array}$ & $\begin{array}{c}\text { Cuts. } \\
-\end{array}$ & $\begin{array}{l}\text { Cwts. } \\
174\end{array}$ & $\begin{array}{l}\text { Cuts. } \\
\qquad 30\end{array}$ & $\begin{array}{l}\text { Cwts. } \\
167\end{array}$ & $\begin{array}{l}\text { Cwts. } \\
-\end{array}$ & $\begin{array}{l}\text { Cuts. } \\
-\end{array}$ & $\begin{array}{c}\text { Cuts. } \\
-\end{array}$ \\
\hline February .............. & - & - & - & 133 & 28 & 55 & - & - & - \\
\hline March $\quad . . . . . . . . . . . . . .$. & - & - & 一 & 17,806 & 10,667 & 1,939 & 1,712 & 2,805 & 275 \\
\hline April .................... & - & - & - & 35,804 & 35,535 & 24,147 & 61,680 & 40,527 & 30,773 \\
\hline May .................... & 63 & 121 & 19 & 41,584 & 62,117 & 93,643 & 64,170 & 77,267 & 41,595 \\
\hline June ................... & 650 & 2,219 & 5,399 & 25,478 & 24,263 & 41,373 & 23,849 & 40,503 & 29,549 \\
\hline July $\ldots \ldots \ldots \ldots \ldots \ldots$ & 21 & 12,757 & 2,964 & 7,686 & 13,012 & 11,459 & 582 & 8,807 & 1,829 \\
\hline August ................ & 98 & 205 & 69 & 3,105 & 4,618 & 6,917 & 477 & 1,381 & 2,333 \\
\hline September .......... & 17,337 & 20,622 & 8,840 & 7,428 & 17,466 & 3,599 & 261 & 735 & 914 \\
\hline October................. & 1,958 & 49,448 & 46,620 & 588 & 8,219 & 2,475 & 15 & 172 & 222 \\
\hline November............. & 1,750 & 8,833 & 14,636 & 388 & 988 & 560 & 32 & 254 & - \\
\hline December ............. & - & - & 215 & 582 & 4,223 & 2,026 & - & - & 4 \\
\hline
\end{tabular}


TABLE IV., showing the quantities of Mackerel landed during each month of the year at certain French ports for the years 1894, 1895, and 1896, compiled from the official returns.

\begin{tabular}{|c|c|c|c|c|c|c|c|c|c|}
\hline & \multicolumn{3}{|c|}{ FRANCE (NoRTH).-ST. VARLEY-SUR-SOMMTE. } & \multicolumn{3}{|c|}{ FRANCE (WEST).-DOUARNENEZ, } & \multicolumn{3}{|c|}{ FRANCE (South),-CEtTE. } \\
\hline & 1894. & 1895. & 1896. & 1894. & 1895. & 1896. & 1894. & 1895. & 1896. \\
\hline January ....... & Kilos. & $\begin{array}{c}\text { Kilos. } \\
-\end{array}$ & Kilos. & $\begin{array}{c}\text { Kilos. } \\
-\end{array}$ & $\begin{array}{l}\text { Kilos. } \\
1,425\end{array}$ & $\begin{array}{l}\text { Kilos. } \\
1,300\end{array}$ & Kilos. & Kilos. & Kilos. \\
\hline February .. & - & - & - & 149,951 & - & - & - & - & - \\
\hline March ........ & - & - & - & 78,932 & - & 34,136 & - & - & 1,840 \\
\hline April ....... & - & 一 & - & 112,300 & $\begin{array}{l}\text { ppearedon 20th } \\
240,000\end{array}$ & 358,581 & 150,200 & 19,400 & 101,354 \\
\hline May.......... & 3,750 & $\begin{array}{c}1,200 \\
\text { Present last } \\
\text { week of month. }\end{array}$ & - & $1,136,625$ & $1,800,000$ & 477,899 & Abundant & 51,050 & 102,650 \\
\hline June & 60,000 & 56,000 & $\begin{array}{c}- \\
\text { Gravelines, } \\
945 \text { kilos. }\end{array}$ & 408,513 & 794,000 & 109,696 & $50,000(?)$ & 52,000 & 47,000 \\
\hline July ... & 66,000 & 70,000 & $\begin{array}{c}84,000 \\
\text { Gravelines, } \\
1,275 \text { kilos. }\end{array}$ & 33,948 & 60,700 & 7,913 & 10,540 & 13,000 & 8,800 \\
\hline August & 75,200 & 59,200 & $\begin{array}{c}33,600 \\
\text { Gravelines, } \\
149,140 \text { kilos. }\end{array}$ & 60,600 & 543,860 & 38,889 & - & - & 7,000 \\
\hline September .... & $\begin{array}{c}88,500 \\
\text { Gravelines, } \\
108,000 \text { kilos. }\end{array}$ & $\begin{array}{l}68,800 \\
\text { Gravelines,* } \\
\text { 66,334 kilos. }\end{array}$ & $\begin{array}{c}41,320 \\
\text { Gravelines,* } \\
\text { 231,460 kilos. }\end{array}$ & $1,042,810$ & 229,870 & 65,734 & - & - & 5,280 \\
\hline October ........... & 8,500 & 8,000 & 8,000 & 203,940 & - & 473,076 & - & - & 2,700 \\
\hline November .............. & - & - & - & 180,000 & - & 48,841 & - & - & 2,006 \\
\hline December .............. & - & - & - & 9,640 & - & 71,491 & - & - & 2,012 \\
\hline
\end{tabular}


TABLE V., showing the quantity of Mackerel landed at various French ports during each month of the year 1896, compiled from the official returns.

\begin{tabular}{|c|c|c|c|c|c|c|c|c|c|c|}
\hline 1896. & Gravelines. & BoULOGNE. & $\begin{array}{l}\text { ST. VARLEY- } \\
\text { SUR- } \\
\text { SOMME. }\end{array}$ & Dieppe. & FECAMP. & DOUARNENEZ. & QUIMPER. & Concarneau. & Cette. & Marseille. \\
\hline & Kilos. & Kilos. & Kilos. & Kilos. & Kilos. & Kilos. & Kilos. & Kilos. & Kilos. & Kilos. \\
\hline January $\quad \cdots+\ldots \ldots+\cdots \cdots$ & - & - & - & - & - & 1,300 & - & 一 & - & 750 \\
\hline February .................. & - & - & - & - & - & - & 1,020 & 1,600 & - & 482 \\
\hline March ...... & - & - & - & - & - & 34,136 & 9,820 & 3,500 & 1,840 & 370 \\
\hline April....................... & - & 681,086 & - & 35,400 & 171,900 & 358,581 & 411,740 & 82,380 & 101,354 & 33,200 \\
\hline May ............... & - & $1,598,136$ & - & 31,700 & 48,157 & 477,899 & 298,000 & 71,710 & 102,650 & 47,300 \\
\hline June ......... & - & 489,550 & - & 60,900 & 47,730 & 109,696 & 95,600 & 17,600 & 47,000 & 55,320 \\
\hline July .......... & 945 & 114,830 & 84,000 & 68,600 & 48,387 & 7,913 & 2,500 & 29,900 & 8,800 & 60,870 \\
\hline August ..................... & 1,275 & 54,000 & 33,600 & 31,400 & 16,170 & 38,889 & 2,400 & 87,800 & 7,000 & 54,000 \\
\hline September .. & 149,140 & 367,200 & 41,320 & 9,200 & 1,374 & 65,734 & 346,000 & 80,030 & 5,280 & 44,800 \\
\hline October........................ & 231,460 & 242,700 & 8,000 & - & 36,720 & 473,076 & - & 67,500 & 2,700 & 20,200 \\
\hline November ................. & 2,375 & 14,520 & - & - & - & 48,841 & - & 2,800 & 2,006 & 7,450 \\
\hline December................... & - & - & - & - & - & 71,491 & - & - & 2,012 & 5,800 \\
\hline
\end{tabular}


also mackerel fishing at this time of the year off the Lizard. The fish taken are smaller than those captured later in the year, and are not mature.

On the west coast of France (Douarnenez) the mackerel may appear in February and remain from that time onwards (e.g., 1894, 150,000 kilos were taken during this month). In other years (e.g., 1895, which was extremely cold during the early months) they were not seen at Douarnenez until the end of April.

Marion* states that at Marseille the ovaries of fish taken in January were well developed. The eggs were $1 \mathrm{~mm}$. in diameter, but were not extruded on pressure. He also mentions small fish 20 to $24 \mathrm{~cm}$. (8 to $9 \frac{1}{2}$ inches) long in February, which he regards as one year old. The reproductive organs of these are stated to have been well developed. Gourret $\uparrow$ records mackerel in January in the same locality, which were 20 to $30 \mathrm{~cm}$. (8-12 inches) long.

No record has been seen of mackerel being taken during either January or February in other parts of Europe than those mentioned.

America.-There is little evidence of mackerel being near the American coasts at this time of the year. Brown Goode $\ddagger$ mentions that instances are on record of mackerel having been captured in the Gulf of St. Lawrence in mid-winter, but these appear to be simply stray specimens. Captain J. W. Collins $\S$ reports that in the latter part of February, 1882, many mackerel were taken from the stomachs of cod, which had been captured 10 to 12 miles off Egg Harbour, N.J., in 12 to 15 fathoms. The mackerel appeared to have been only recently swallowed. This observation is important, since it shows that mackerel may be at no great distance from the coast without their presence being easily detected.

MARCH AND APRIL: Europe.-During the early part of March, and often during the greater portion of the month, the conditions remain much as they were during February. The mackerel in the English Channel are still 20 to 40 miles from the coast, and they remain at about this distance during the whole of these two months, increasing, however, in abundance.

Towards the end of March, or early in April, large schools of fullgrown fish approach the south-west coasts of Ireland and the west coast of France, and the great spring mackerel fishery commences.

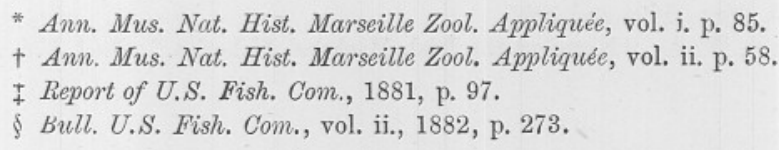


The date of the appearance of the spring shoals varies considerably from year to year. As already mentioned, in 1894 the fish were taken in numbers on the west coast of France, at Douarnenez and the neighbouring fishing ports, as early as February. In the following year, 1895, none were seen at Douarnenez until the 20th of April, whilst at Quimper they first appeared on March 22nd.*

The following dates, taken from the Reports of the Inspectors of Irish Fisheries, give the times of commencement of the fishery for different years at some of the principal Irish fishing ports :-

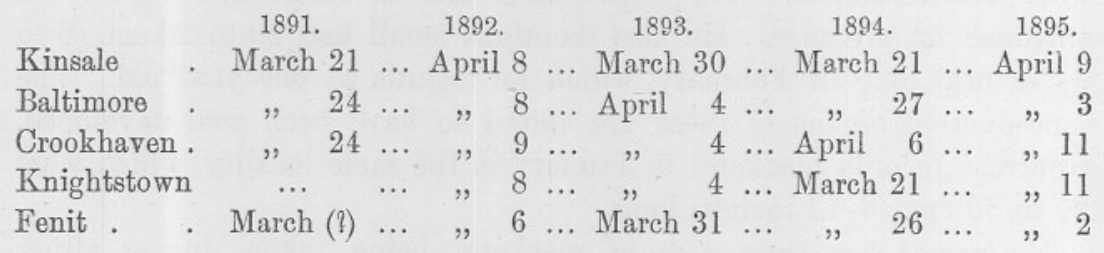

Comparing the dates of arrival of the large shoals in the years 1894 and 1895 on the south-west coast of Ireland, and those already given for the west coast of France, it appears that the fish came earlier in 1894 than in 1895 in both localities, and in both years reached the French coast earlier than the Irish, the difference in time being from a fortnight to a month. In 1895, although the mackerel were at Quimper earlier than in Ireland, they did not appear at Douarnenez until some ten days after the commencement of the Irish fishery.

It is worthy of note that in certain bays on the west coast of Ireland the large fish are taken in nets shot from canoes and row-boats close to the shore some two or three weeks before they are captured by the larger vessels working in the offing, where the water is 40 to 80 fathoms deep. $\dagger$ As Mr. Green has pointed out, this seems to indicate that the mackerel when approaching the shore keep deep down, the fish which enter the bays being forced up into the upper waters by the rising of the sea-floor.

At about the same time as the appearance of the schools off the west coasts of France and Ireland - that is, towards the end of March-mackerel fishing commences in the Mediterranean. Large schools are found off Cette, on the south coast of France. At Marseilles, on the other hand, the fish do not enter the Gulf until considerably later.

* Bull. Péch. Mar., 1894 and 1895.

+ Green, Rev. W. S. "Notes on the Irish Mackerel Fisheries," Bull. U.S. Fish. Com., 1893, p. 357. 
One important observation made during the early days of March, 1891, is recorded by Marion,* which shows that mackerel may be present in deep water when not visible at the surface. After a strong mistral the trawls of the "bateaux bœufs," fishing six miles from shore off Cape Couronne, caught numbers of mackerel at depths of 100 to 150 mètres. Marion considers that this accidental capture demonstrates completely that the mackerel leave the surface and descend into the deep water when the upper layers are agitated by strong winds. This observation will be again considered and discussed in relation to others.

After the advent of the spring schools fishing is abundant in the Mediterranean (Cette), off the west coast of France, off the south-west of Ireland, in the western portion of the English Channel, and off the north coast of Cornwall. Mackerel are not, however, yet (April) taken in numbers in the eastern portion of the English Channel, in the North Sea, or on the coast of Norway.

In the Mediterranean the mackerel caught in April are breeding fish. On the other coasts the shoals are composed of large fish about to breed, but their reproductive organs are not yet ripe. The fish captured off the south-west of Ireland appear to be the finest, and command the best prices.

America.-On the Arnerican side of the Atlantic mackerel make their first appearance at some distance from the coast, off Cape Hatteras, at about the same time of year as they appear on the Irish coast. The following list of dates of first catches is taken from the Bulletin of the U.S. Fish Commission, vol. vi., 1886, p. 107.

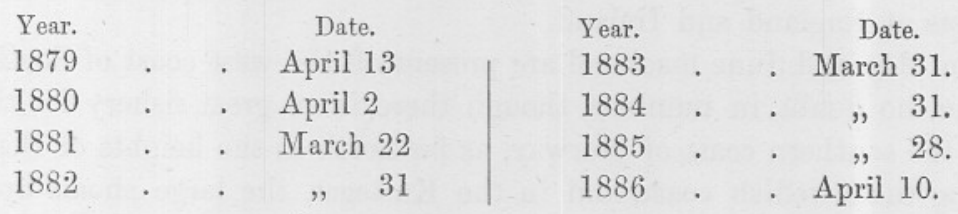

During April the fish move gradually northwards, but do not go close to the shore. By the end of the month they are generally found off the capes of Delaware.

Until the year 1886 it was the custom of the American mackerel fishermen to go southwards in March, and capture these early shoals. Many of the shoals were composed of large fish just about to spawn, but the condition of the fish was not equal to that of those caught later in the year, which had been feeding on the coast for some time. As the fish did not readily take bait at this time, they were caught in purse-seines. In 1887, to endeavour to counteract the considerable

* Ann. Mus. Nat. Hist. Marseille Zool. Appliquées, 1891, p. iii. 
decline of the mackerel fishery, an Act was passed by Congress prohibiting the landing of mackerel between the first day of March and the first day of June for a period of five years, the Act not to apply to fish caught off-shore with hook and line. As no great good was seen to result from this restriction of the fishery of the breeding fish, the Act was not renewed after its expiration in 1892.

MAY AND JUNE: Europe.-In May the spring mackerel fishing reaches its height, and continues into June, falling off considerably towards the end of that month. In the Mediterranean (Cette), on the west coast of France, on the south-west coast of Ireland, and in the western part of the English Channel, during both May and June, the fish are near the shore in large numbers, the quantities landed in all these localities being at a maximum in May. With the exception of the Mediterranean fish, which are all spent, spawning is actively going on. Mackerel are plentiful during both these months on the coast of Portugal.*

In the eastern portion of the English Channel (e.g., St. Varley-surSomme) the fish are seldom abundant before June.t At Dieppe, however, some mackerel are taken in both April and May, but the maximum is not reached until June. At Guernsey fishing begins at the middle or end of May, and lasts ten to twelve weeks. $\neq$

In the North Sea there is a small fishery on the Danish coast, which commences in May; but no fish are landed at the English North Sea ports before June, and then they are not numerous in proportion to those taken later in the year. The large Lowestoft and Yarmouth mackerel boats are at this time of the year working off the south-west coasts of England and Ireland.

In May and June mackerel are present off the west coast of Scotland, often, no doubt, in numbers, though there is no great fishery for them. On the southern coast of Norway, as far north as the heights of Bergen, along the Swedish coast, and in the Kattegat, the large shoals appear towards the end of May, and the principal fishery is carried on during the latter part of that month and in June.

In general it may be said that in the more southerly and westerly districts, where the fish arrive in April, they are most abundant in May, whilst in the northerly and easterly ones they do not arrive until towards the end of May, and are most abundant in June.

* Baldaque da Silva. Estado Actual das pescas em Pordugal. See also Mitt. Deutsch seefischereivereins, 1895, p. 61.

+ In exceptional years mackerel may be taken in this part of the Channel in numbers in February and March. In March, 1833, and in February and March, 1834, according to Yarrell, boats from Hastings had large catches; but it is not stated where the fish had been captured. Yarrell. British Fishes, pp. 125, 126.

$\ddagger$ Holdsworth. Deep-sea Fishing, p, 213. 
It should be mentioned that in the English Channel and in the Mediterranean, although the fish are close in-shore along the coast in May, they do not enter Plymouth Sound and the Gulf of Marseille in great numbers until later, in the former case not until July, in the latter in June.

America.-We have already seen that towards the end of April the mackerel on the east coast of the United States are taken as far north as the capes of Delaware, but still at some distance from land. About the beginning of May the fish approach the coast in the neighbourhood of Long Island. They are present at about the same time in abundance in the neighbourhood of Nantucket and in Massachusetts Bay. Towards the end of the same month they are first taken off Nova Scotia (May 20th, 1883; May 16th, 1884), but it is often much later than this when they appear in the Gulf of St. Lawrence. At the Magdalen Islands, near the mouth of the Gulf, mackerel most frequently arrive during the first week in June. In 1884, which was a very late year, owing to the fact that the ice did not leave the Gulf until June 2nd, no mackerel were taken until August.* When the fish are late in appearing on the Massachusetts coast they are generally proportionately late in reaching the Gulf of St. Lawrence. The years 1871 and 1872 offer a good example of this, as will be seen from the dates given below :-†

\section{Waquoit, Massachusetts.}

1871. Date of first appearance of mackerel, April 25th.

1872. " " " " " May 10th.

Difference in time, 15 days.

Magdalen Islands, Gulf of St. Lawrence.

1871. Date of first appearance of mackerel, May 31st.

1872. " " , , , " June 20th.

$$
\text { Difference in time, } 21 \text { days. }
$$

With reference to the passage of the mackerel into the Gulf of St. Lawrence, Captain J. W. Collins, of the U.S. Fish Commission, $\neq$ states that during May and early June large bodies of these fish pass along the shores of Nova Scotia and Cape Breton, from west to east, some entering the Gulf by the Straits of Canso, others going round the north of Cape Breton Island.

July ANd August.-Europe. At all the large fishing centres there is a great falling off in the quantity of mackerel landed during these

\footnotetext{
* Bull. U.S. Fish. Com., vol. v. p. 60.

+ Report of U.S. Fish. Com., 1881, p. 136.

$\ddagger$ Report of U.S. Fish. Com., 1881, p. 121.
}

much better condition than those taken in spring, owing to the more

\footnotetext{
* Cunningham. Nat. Hist. Mark. Mar. Fish., p. 316.
} 
two months. On the south-west of Ireland fishing is almost suspended, and the quantities caught on the south and west coasts of England and on the west coast of France are very small compared with those taken during May and June.

In the eastern part of the English Channel and on the east coast, where the mackerel do not arrive until the end of May, the returns indicate that the fish are more numerous in July than earlier in the year; but there is a falling off in the number landed in August, which is, however, more marked in the North Sea than in the English Channel.

In Norway the fishing, which commences towards the end of May, and is at its height during June, continues to be good until the middle of July, about which time it practically ceases. Sars* draws attention to the fact that, according to Lowe (Fauna Orchadensis), mackerel are seen in large schools near the Orkney Islands at the end of July and the beginning of August, just after the Norwegian fisheries have closed. These he thinks are probably shoals returning from the Norwegian coast to the Atlantic.

In the Mediterranean, at Cette, and at the majority of the ports, the large fishing practically ends in June, and few mackerel are taken during the remainder of the year. At Marseilles, on the other hand, the fish seem to be plentiful until September. In 1896, according to the official returns, the maximum was reached in July, and the quantity taken in August was still large. Marion $†$ states that the fish are generally most plentiful in September.

From the above facts, which will be seen in more detail in the tables, it is obvious that as a general rule a season of scarcity exists during these two months, July and August, between the great spring and autumn fisheries. The reason for this scarcity is not very clear. At Plymouth, at this time of the year, the mackerel seem to be scattered. There are undoubtedly large numbers present in the Sound and in-shore waters, where they are taken by whiffing and with the seine. Drift-net fishing, on the other hand, is practically suspended. It is to be noted, too, that during the hot weather of these two months mackerel are with difficulty kept in good condition, and although the supply is short the demand for them is not great, and prices are low. It is probable that this may have something to do with the small quantity landed.

America.-The marked falling off between the spring and autumn fisheries, which is observed in Europe, does not, from the information available, appear to be so great on the American coasts, if indeed it exists at all. In Fundy Bay, and in the Gulf of St. Lawrence, at any rate, the fish seem to be quite plentiful at this time of the year.

* Report for 1875. English Translation, Report of U.S. Fish. Com., 1877, p. 671.

† Ann. Mus. Nat. Hist. Marseille Zool. Appliqué, i. p. 84. 
SePtember AND OctoBer.-Europe. During September and October the great autumn mackerel fisheries are carried on. On the west coast of France and the south-west of Ireland large numbers of fish are taken, the amount landed in Ireland being as great in some years as during the spring fishery. The fish are of good size and in good condition, but their reproductive organs are not mature. There appears to be a general idea amongst the fishermen that the autumn fish, both here and elsewhere, belong to a different race from those takeu in the spring, but no successful attempt has ever been made by naturalists to prove or disprove this contention.

On the west coast of England an autumn fishery practically does not exist, and on the south coast, although more fish are in general landed in September than in August, the number is by no means large, and October shows a very great falling off. At Plymouth the mackerel leave the Sound after the beginning of September, and are then taken a few miles south of the Eddystone and off Start Point.*

In the eastern portion of the Channel (e.g., St. Varley-sur-Somme), and in the southern part of the North Sea (east coast of England and Gravelines), on the other hand, by far the most important fishery of the year takes place at this time, the number of fish landed being greatest in October.

In Norway there is an autumn fishery of mackerel, which crowd into the deep-water fjords. These fish are feeding on the young herring and other small fish, and are in extremely good condition. As soon as the food gets scarce they go to sea again. Sars considers that they are schools which have separated from the chief summer schools, and instead of going out to sea, have commenced to chase the young herring and follow them into the fjords. Sars also states that these autumn fish frequent deeper water than the summer mackerel, probably because of the fresh water at the surface of the fjords.

On the French Mediterranean coast the only important autumn fishery is at Marseilles, there being practically none at Cette.

America.-In America, as in Europe, autumn fishing for mackerel is largely carried on. The vessels at this time of the year work chiefly in the Gulf of St. Lawrence, but mackerel are also taken along the New England coast. The information contained in the various reports of the United States Fish Commission does not, however, indicate that any marked increase of fish in September and October, over that taken during the two preceding months, regularly takes place, as we find to be the case in European seas. The autumn fish are in much better condition than those taken in spring, owing to the more

* Cunningham, Nat. Hist. Mark. Mar. Fish., p. 316. 
plentiful supply of food in the shape of young fish of other species. The idea, which is so prevalent amongst fishermen on the English coast, that the mackerel taken in the autumn are a different race of fish from those taken in spring, does not seem to be suggested by the American fishermen.

November and December: Europe.-Mackerel fishing is practically closed in November and December on all the European coasts, though a few fish are still taken in the North Sea in November, and a still smaller number in the English Channel. Mackerel landed at Plymouth are caught 15 to 20 miles south-west of Start Point, and about the same distance from the Eddystone. On the west coast of France the fish may be entirely absent, or a small number may be taken in both November and December. On the south coast of Ireland, in favourable years, fishing on a small scale may be continued up to Christmas.

America.-In America fishing ceases and the mackerel fleet is laid up in November. The fish are observed to leave the Gulf of St. Lawrence in large shoals, passing out by the same routes as they entered, viz., around the north of Cape Breton Island or through the Straits of Canso,* and they remain absent until the following summer.

Extent and Causes of the Migration of the Mackerel.-Both the extent of the migrations of the mackerel, and the causes which bring about those migrations, are very imperfectly understood. For a long time both have been subjects for speculation amongst naturalists, but little definite or certain information has been arrived at.

Brown Goode, $\uparrow$ who has discussed the general question of the migrations of pelagic fishes with some fulness, regards the temperature of the sea-water as one of the most important factors influencing their movements, and this view is shared by most naturalists who have paid attention to the subject. According to Brown Goode the appearance of the mackerel off the coast of America is synchronous with an average weekly temperature of not less than $45^{\circ} \mathrm{F}$. in the harbours. At this time the temperature in the open sea is somewhat lower, and mackerel will remain active and contented at a temperature of $40^{\circ}$, or even less. Green $\ddagger$ has shown that on the south-west coast of Ireland mackerel are first taken in the spring in large numbers off the land when the surface temperature of the sea is $50^{\circ} \mathrm{F}$. At the same time he mentions that the smaller boats, shooting their nets close to the shore and in

- Collins, J. W. Report of U.S. Fish Com., 1881, p. 121.

† "History of the Menhaden." U.S. Fish. Com. Report, 1877, especially pp. 50-70. "Materials for a History of the Mackerel Fishery." U.S. Fish. Com. Report, 1881.

‡ "Notes on the Irish Mackerel Fisheries." - Bull. U.S. Fish. Com., 1893, p. 357. 
certain bays, get the large spring fish two or three weeks earlier, whilst the temperature is still low.

In the south of France, where the migrations are essentially similar to those which occur in America and on the Atlantic coasts of Europe, the temperature of the surface water on the coast is never below $50^{\circ} \mathrm{F}$. $\left(10^{\circ} \mathrm{C}\right.$.), even in January, the temperature in February and March being $54^{\circ}$ to $59^{\circ} \mathrm{F}$. $\left(12^{\circ}-15^{\circ} \mathrm{C}\right.$.) [Marion.]

From these facts it would seem that the large shoals first appear in American waters when the temperature is $40^{\circ}-45^{\circ} \mathrm{F}$.; off the coast of Ireland when it reaches $50^{\circ} \mathrm{F}$., and on the Mediterranean coasts when it approaches $60^{\circ} \mathrm{F}$. We must, therefore, suppose either that we are here dealing with three distinct races, which have become adapted to different temperature conditions, in which case the species must be capable of considerable variation in its habits in this respect, or that the temperature influences the migrations of the fish indirectly by determining the presence or absence of the particular organisms which serve for its food in each locality. The latter explanation, however, cannot be regarded as complete, since in some localities, e.g., the North Sea, in autumn we have both herring and mackerel present at the same time, yet whilst the mackerel retire to the south the herring return to the north.

The first approach of the mackerel to the coast in spring or early summer is for the purposes of spawning, and the advantage to the species of the young fish being hatched out near the shore, where the smaller forms of pelagic organisms are present in abundance, and the plankton is increased by the numerous larval forms of those species which inhabit the coastal waters, is obvious. The presence of the fish in the in-shore waters during the summer and autumn, on the other hand, is to be explained by the fact that these waters are at that time crowded with the young forms of other fishes, which serve as a bountiful food supply to the mackerel.

It has already been noted that when the fish first approach the coast for spawning only the males can be captured with bait, the females having ceased to feed at this time. Hence the first migration towards the shore must be regarded as to some extent independent of the food supply, and we may call it, with Sars, the "spawning migration." The approach to the coast in the summer and autumn is, on the other hand, a "feeding migration."

What relation exists between the fish which take part in the two migrations it is impossible to say. The autumn fish are said to be smaller than those which come in the spring, and it has already been mentioned that the fishermen maintain that they belong to a different race. They are all of them, however, immature, and cannot 
therefore be compared to the winter and summer herrings, both of which are spawning fish, when they visit the coasts.* Sars regards the autumn fish, which in Norway are taken in abundance in the fjords, as fish which have left the main shoals in summer to follow the young herring upon which they feed.

Where do the mackerel go when they leave the coast? is perhaps the most important question connected with their migrations, to which no certain answer can yet be given. Sars and Brown Goode have both shown that the theory at one time held by some naturalists, that the fish hibernate during the winter at the bottom of the sea, in the neighbourhood of their summer haunts, is highly improbable, and it need not be further discussed here.

There are two alternatives in regard to the matter which are worthy of consideration.

(1) The mackerel may live near the surface of the ocean at considerable distances from land, in regions where they find a suitable sea temperature.

(2) They may live in deeper layers of the sea, at a greater or less distance-possibly never at a very great distance-from their summer localities, where it is possible that they may find the conditions favourable.

1. That the mackerel during the winter do not retire to more southerly latitudes, and continue to live according to their spring and autumn habits, near the coast and at the surface, is practically certain. There is no record of the fish being taken either on the coast of Africa or on the American coast, south of Cape Hatteras, during the cold months of the year.

Nor do any accounts exist of mackerel having been seen at the surface in the warmer regions of the open ocean at any time of the year. If they made these regions their winter home, and preserved their shoaling habits, it is practically certain that they would have been recognised, as the appearance of the shoals is well known to seafaring men, and is quite characteristic. If, on the other hand, the shoals broke up and the fish wandered independently or a few only together, it is possible that they might have escaped detection. This must remain, until the contrary is shown to be the case, one of the possible solutions of the question, although it is not very probable, since were it so specimens would almost certainly have been captured at some time or other.

2. The mackerel may live in deeper layers of the sea, at a greater or less distance-possibly at no very great distance-from their summer haunts. The facts on the whole seem to point to this conclusion.

* Cunningham. Nat. Hist. Mark. Mar. Fish., p. 153. 
That on the first appearance of the fish a certain amount of migration in a definite direction, generally from south to north, takes place cannot be denied. It is most conspicuous on the American coast, where the fish, as has been explained, first appear at some distance from land off Cape Hatteras, and gradually move northward until they reach the coast in the neighbourhood of Long Island, about a month after they are first seen. Even in this case, however, it is fairly obvious that large numbers of fish must be moving in towards the land from latitudes more northerly than that of Cape Hatteras, where the fish first appear.* The fact that the spawning season of the mackerel becomes later the further north they are captured is sufficient in itself to prove that such is the case. The fish which spawn in the Gulf of St. Lawrence in July cannot be the same as those which spawned in May and June on the New England coast. In the autumn, too, when the fish disappear, the facts do not point to an extensive southerly migration in the surface waters along the coasts. That the fish move out of the Gulf of St. Lawrence seems to have been established, but this does not take place until November, and the fishing is continued in this region quite as long as it is further south. There is practically no fishing on the more southerly coasts of the United States after the fishing in the Gulf has ceased.

On the Atlantic coasts of Europe the movements of the mackerel, after their first appearance, are a little more difficult to follow. Unfortunately no information has been found in the literature consulted as to when the fish first arrive off the coast of Portugal, and we only know that they are plentiful from May onwards. The earliest catches on this side of the Atlantic of which records exist are those made in the western part of the English Channel in January and February, and some also off the west coast of Ireland. In the former case the boats generally obtain their first fish about 20 miles south-west of Start Point, and subsequently work more to the westward, taking them 20 miles south-west of the Eddystone. This seems to suggest that we have here to do with the last of the autumn fish of the previous year moving down Channel.

On the west coast of France the spring shoals may appear as early as February (e.g., 1894), although in other years none may be taken until late in March or April. It is generally somewhat later that the fish arrive off the mouth of the Channel and off the Irish coast. In Norway and the Kattegat the fish do not come to the coast until towards the end of May, and the fact that the spawning season of these fish is so much later than that of those in the Channel would, in this case also,

"See especially Spencer Barrd, "Sea Fisheries of Eastern North America," and Appendix. lieport of U.S. Fish Com., 1886. 
render it unlikely that they had made any extended migration along the Irish and Scottish coasts.

There is, however, obviously a migration through the English Channel into the North Sea. Whilst mackerel are at the mouth of the Channel in March few fish are taken either in its eastern portion or in the southern part of the North Sea before the end of May or the beginning of June. In the autumn, on the other hand, the large fishery in the southern part of the North Sea seems to be due to the movement of the fish towards the Straits of Dover, on their passage back to the English Channel. The mackerel taken on the south coast of England in December, January, and February are possibly, as suggested above, the fish which have emigrated from the North Sea. In the present state of our knowledge of the subject this is, however, a mere speculation. An examination of the Board of Trade statistics from 1886 to 1895 does not show any constant relation between the number of mackerel landed on the south coast of England in December and January, and the success or failure of the previous autumn fishery on the east coast.

There is a certain amount of evidence that mackerel, when not at the surface near the coasts, may be present in deeper water not far off. This evidence has already been referred to in previous parts of this Report. In the first place there is the fact mentioned by Green, that in certain bays on the west coast of Ireland the large spring mackerel are captured close to the shore two or three weeks before the larger boats working in the offing, where the water is 40 to 80 fathoms deep, are able to obtain any. These early in-shore fish must have travelled in towards the coast in the deeper layers of water. There is also the record by Marion, that at the beginning of March, 1891, after a strong mistral, large numbers of mackerel were taken by the trawls of the "bateaux bœufs," fishing six miles from shore off Cape Couronne, in depths of 100 to 150 mètres. It is true that in this case the objection may be raised that the fish might have been captured in upper layers whilst the net was being drawn to the surface, but this does not appear to be a very likely explanation of the catch. Mr. Holt states that he has taken mackerel in the trawl in the North Sea, after heavy weather, and the Plymouth trawl fishermen say that they also obtain them under like circumstances.

Finally, we have the records of mackerel, but little digested, taken from the stomachs of cod on the American coast some time before the appearance of the schools at the surface.

If the mackerel, when away from the coast, retire to deeper water, where the temperature is more suitable to them, it becomes interesting to inquire where they would find such a temperature. The series of 
observations taken by the Challenger between Bermuda and Halifax, and New York and Bermuda, which are shown in two diagrams in Brown Goode's paper on the "Menhaden Fishery," * prove that on the western side of the Atlantic extensive layers of water exist in April and May below the Gulf Stream having temperatures similar to those of the waters frequented by the mackerel when on the coast.

For the parts of the Atlantic lying off the European coasts no observations giving the required information during the winter months appear to have been made; but from the position of the isothermal for $50^{\circ} \mathrm{F}$. for surface temperature in February, when such temperatures are at a minimum, it is clear that water of the required warmth must exist at no very great distance from the coasts frequented by the fish, with the exception of the coasts of Norway and the North Sea. In the latter case we have already seen that the fish probably retire in the autumn by way of the English Channel.

* Report of U.S. Fish. Com., 1877. 